\title{
Integrální výchovou k integrálnímu humanismu: Jacques Maritain a jeho fillozofie výchovy Helena Zbudilová
}

\begin{abstract}
Abstrakt:
Článek se soustřed'uje na pedagogický odkaz díla novotomistického filozofa Jacquesa Maritaina (1882-1973). Jeho filozofie výchovy je hledána zejména v perspektivě personálního a integrálního principu edukace a s ohledem na autorovu tezi o „integrální výchově směřující k integrálnímu humanismu“. Článek přináší přehled autorovy pedagogické a publikační činnosti. Jeho dílo Humanismus intègral (1936) usouvztažňuje se závěry autorových zásadních pedagogických děl: Education at the Crossroads (1943), The Education of Man (1963) a Pour une Philosophie de I'Ėducation (1959, 1969). Osoba jako ústřední bod Maritainovy filozofie výchovy je nazírána prizmatem požadavku obnovy lidství v současném výchovně-vzdělávacím procesu. Na základě kritické reflexe tehdejších pedagogických teorií dospěl autor k vlastní definici výchovy a vzdělávání a k charakteristice cílů edukace, role učitele a žáka/studenta ve výchovně-vzdělávacím procesu. Vedle těchto závěrů se text zabývá některými aktuálními problémy současného školství z pohledu Maritainova myšlenkového odkazu: např. náboženskou a etickou výchovou, studiem literatury (The Great Books), pedagogikou volného času, celoživotním vzděláváním, problematikou specializace. Závěr je věnován zařazení Maritaina mezi vrcholné představitele novotomistické orientace integrálního personalismu. Jeho pedagogická koncepce přináší holistický přístup, navazuje na perennialistické edukační teorie a představuje pedagogiku hodnot (pedagogiku kultury).
\end{abstract}

Klíčová slova: Jacques Maritain, integrální humanismus, teocentrický humanismus, neotomistická pedagogika, neotomistický integrální personalismus, filozofie výchovy, principy edukace, náboženská výchova

„Jestliže je pravda, že naše hlavní povinnost podle hluboké zásady Pindarovy tkví v tom, abychom se stali tím, čím jsme, pak není pro každého z nás nic důležitěǰsího a nic těžšího než stát se člověkem." (J. Maritain, Education at the Crossroads, 1943) 
„... abychom dosáhli jednoty víry a poznání Syna Božího, a tak dorostli zralého lidství, měřeno mírou Kristovy plnosti.“"

$($ Ef 4,13$)$

\section{Úvod}

S nástupem 21. století je stále zřejmější, že epoše globalizace a multikulturality je zapotřebí filozofie výchovy pevně zakotvené v humanistické tradici. Smyslem humanistické výchovy a vzdělávání je obnovit lidství a pozvedat člověka $\mathrm{k}$ jeho vyšším stupňům. Je třeba znovu si položit otázku „Kdo je člověk?“ a jaký typ lidství je nutno rozvíjet pro jeho záchranu před dezintegrací v současné společnosti. Cesta integrální výchovy směřující k integrálnímu humanismu se stává naléhavým poselstvím pro dnešní dobu. Jako světlu v tomto kontextu dává vyzáriit dílo Jacquesa Maritaina, jednoho z nejvýznamnějších představitelů novotomistické filozofie, neotomistického personalismu. Jeho dílo představuje propojení světa teologie, filozofie a umění a zároveň oslovuje svět pedagogiky integrálním pojetím edukace. P. Georg-Maria Cottier označuje Maritainovo dílo za teo-filozofii; integritu teologie, filozofie a mystiky. ${ }^{1}$ Podle Carlo Hubera Maritainova politická koncepce a pedagogika přispěly ke sjednocení Evropy. ${ }^{2} \mathrm{~V}$ českém prostředí však Maritainův pedagogický odkaz žije spiše ve stínu zejména jeho politické filozofie a autorova více než čtyřicetiletá publikační činnost $\mathrm{v}$ oblasti výchovy a vzdělávání zůstává (až na výjimky) spíše neznámou. Zásluhou Miroslava Cipro byl Maritain zařazen do galerie světových pedagogů v jeho díle Prameny výchovy IV (1995). Kniha přináší 24 stran textu věnovaných Maritainově pedagogické koncepci. Tento článek je pokusem o reflexi Maritainovy filozofie výchovy (z pohledu jeho zásadních děl publikovaných $\mathrm{v}$ angličtině a francouzštině) v perspektivě pedagogického myšlení 21 . století.

\section{Maritain jako edukátor a autor}

Jacques Maritain o výchově a vzdělávání nejenom psal, ale též se věnoval vlastní pedagogické činnosti. V roce 1914 se stal profesorem moderní filozofie v Katolickém institutu v Paříži, působil zde do roku 1939. Od 30. let se jeho pedagogická činnost rozšiřuje i do dalších zemí. V letech 1932-1933 uskutečnil přednášky na Papežském institutu středověkých studií v Torontu, v roce 1934 na univerzitě v Santanderu ve Španělsku. Počátkem roku 1940 má Maritain přednášet v New Yorku, nakonec zůstane v USA po celou dobu druhé světové války. Přednášel na Kolumbijské, Princetonské, Chicagské, Yalské a Notredamské univerzitě. Do dějin pedagogiky vstoupily jeho přednášky „Terry Lectures“ odprezentované na Yalské univerzitě v roce 1943. Ve stejném roce byly publikovány knižně pod názvem Education at the Crossroads (Výchova na rozcestí). V roce 1948 se Maritain do Ameriky vrátil. Byl jmenován profesorem na Princetonské univerzitě a působil zde do roku 1960. V posledních desetiletích svého života poskytoval v Toulouse semináře Malým bratř́m Ježíšovým Charlese de Foucoulda, kongregaci, ke které se připojil po smrti své manželky. ${ }^{3}$ Jako učitel byl Jacques Maritain vždy př́íladem filozofické angažovanosti křestanského myslitele. V Maritainově meziválečné publikační činnosti lze spatřovat počátky jeho pozdějšího soustavného zájmu o problematiku nové pedagogické koncepce. $Z$ autorova pera vzešlo celkem 41 prací

1 Srov. Helena HREHOVÁ, Morálna filozofia Jacquesa Maritaina: Reflexie o etike a morálke, Trnava: Filozofická fakulta, Trnavská univerzita, 2011, s. 191.

2 Srov. tamtéž, s. 196.

3 Srov. Klára JELÍNKOVÁ, Jacques Maritain v datech, Salve 2/2006, s. 119-124. 
o výchově a vzdělání (včetně časopisecké produkce). ${ }^{4}$ Tohoto tématu se dotýkal i v řadě svých děl o estetice, morálce a politice. První poválečná autorova studie nazvaná Le Problème de l'Ècole Publique en France (Problém veřejné školy ve Francii, 1946) se týkala reformy francouzského školství. Zásadní pedagogické dílo představují dvě publikace vydané v angličtině: Education at the Crossroads (Výchova na rozcestí, 1943) a The Education of Man: The Educational Philosophy of Jacques Maritain (Výchova člověka: Filozofie výchovy Jacquesa Maritaina, 1963); a jedna publikace vydaná ve francouzštině: Pour une Philosophie de l'Education (K filozofii výchovy, 1959 a 1969). Poslední dvě zmiňované knihy přinášejí text Výchovy na rozcestí a některé shodné kapitoly. Obě představují ucelenou koncepci filozofie výchovy. Druhé upravené vydání knihy Pour une Philosophie de l'Education z roku 1969 je závěrečnou souhrnnou systematizací autorových pedagogických názorư. ${ }^{5}$

Maritainovy úvahy o školství se rozvíjely zásadním způsobem mezi lety 1940 až 1960, kdy přednášel na nejprestižnějších amerických univerzitách. Filozofoval o výchově a vzdělávání v době společenské krize a nejistot doby válečné i poválečné. Je zajímavé sledovat první a poslední vydání jeho klíčových pedagogických děl z hlediska jejich geneze. Education at the Crossroads (Výchova na rozcestí, 1943) je reakcí na druhou světovou válku. V knize Pour une Philosophie de l'Education (K filozofii výchovy, 1959) zaznívají odezvy na hnutí hippies v 60. letech a v novém vydání z roku 1969 též reakce na hnutí roku 1968 ve Francii. Varuje-li autor v první knize před nacistickým totalitarismem, poslední publikace vyznívá jako varování před technokratismem, konzumerismem, zvěcněním člověka a neukotvenou absolutizací svobodné volby. $\mathrm{V}$ jeho díle najdeme kritické odezvy na soudobé pedagogické směry, zejména na tehdy populární pragmatismus. Maritainova metafora „vzdělání na křižovatce“ zůstává stále aktuální. Humanistická pedagogika je společnou platformou. Ale kterým směrem pokračovat s ohledem na současný stav společnosti a krizi výchovy, jež je de facto krizí člověka? Cestou antropocentrického nebo teocentrického humanismu?

\section{Integrální humanismus}

Maritainova často citovaná teze o „integrální výchově směřující k integrálnímu humanismu“ ${ }^{\text { je }}$ výrazem autorova volání po novém humanismu, novém křestanství. Tuto vizi moderního křestanství a představu postkapitalistického společenského pořádku vybudovaného na křestansko-personalistickém základu přináší autor v knize Humanismus Intègral (1936, česky Křestanský humanismus, 1947 a Integrální humanismus, 1967). V této dnes již kultovní knize generací katolických intelektuálů je nové křestanství integrálním humanismem, humanismem Vtělení, „který má být nejen motivovaný, ale i strukturovaný tak, aby respektoval nedotknutelnost člověka jako osoby, zakořeněné $\mathrm{v}$ transcendentnu, otevřené působení milosti a na živý vztah s Bohem, který posvěcuje a zachraňuje“.7 Integrální humanismus se realizuje jednoznačně na teocentrickém základě a „tíhne svou podstatou $\mathrm{k}$ tomu, aby učinil člověka pravdivěji lidským a zjevil mu jeho původní velikost, poskytuje mu účast na všem, co ho může obohatit v př́rodě i v dějinách“. ${ }^{8}$ Podle Maritaina je současnost tragédií ducha epochy, který se chtěl odtrhnout od Boha a jeho zákona. ${ }^{9}$ Antropocentrický humanismus, obracející se na člověka jako na „střed sebe sama“, a tedy

4 Luz M. IBARRA, Maritain, Religion and Education: A Theocentric Humanism Approach, American University Studies: Peter Lang Publishing Inc., 2013, s. 74.

5 Miroslav CIPRO, Prameny výchovy. IV, 20. století, Praha: Miroslav Cipro, vlastním nákladem, 1995, s. 171.

6 Jacques MARITAIN, Education at the Crossroads, New Haven: Yale University Press, 1943, s. 88.

HREHOVÁ, Morálna filozofia Jacquesa Maritaina..., s. 190.

Jacques MARITAIN, Integrální humanismus, Rím: Křestanská akademie, 1967, s. 10.

9 Juraj LAUKO, Krátký náčrt personalistickej sociálnej filozofie Jacqua Maritaina, Filozofia 3/2005, Filozofický ústav SAV, s. 198. 
i všech věcí, označoval Maritain za „nelidský“ a jeho dialektiku chápal jako tragédii humanismu. V knize Integrální humanismus, která vznikla na základě autorových přednášek uskutečněných na univerzitě v Poznani a Santanderu, vytyčuje autor úkol jednat „jakožto křestané“ (na rovině duchovní) a „po křestansku“ (na rovině politické). ${ }^{10}$ Maritain byl jedním z inspirátorů Všeobecné deklarace lidských práv přijaté Valným shromážděním Spojených národů v prosinci 1948. Jedním ze zásadních bodů této deklarace je i právo každého člověka na vzdělání. Maritainova myslitelská činnost ovlivnila i kulturní instituci UNESCO zejména myšlenkami o koncepci člověka, světa a kultury. Maritain je spoluautorem textu Deklarace práv dítěte vydaných OSN v listopadu 1959. Maritainovy myšlenky nového humanismu našly svůj ohlas i u papeže Pavla VI., který ve svém projevu v roce 1965 na zasedání II. vatikánského koncilu uvítal nástup humanismu „opravdového a plného lidství" (integer homo). ${ }^{11}$ Maritain byl inspirací i pro papeže Jana Pavla II., a to zejména v oblasti ekumenismu. ${ }^{12}$ Podle Nikolaje Berdajeva Maritain „je prvním, kdo uvedl tomismus do kultury“. Stal se též klíčovou postavou v aplikaci novotomismu na oblast výchovy a vzdělávání.

\section{Personalistický pohled na výchovu}

Maritainův integrální humanismus předkládá personalistický pohled na výchovu. Ústředním tématem, které se prolíná celou autorovou tvorbou, je problematika člověka a jeho plného uskutečnění jako individuální osoby v kontextu pluralitní společnosti uspořádané v demokratickém systému. S tímto klíčovým tématem úzce souvisí tématika výchovy a vzdělávání. ${ }^{13}$ Maritain v knize The Education of Man: The Educational Philosophy of Jacques Maritain (Výchova člověka: Filozofie výchovy Jacquesa Maritaina) definuje člověka z hlediska filozoficko-náboženské dimenze lidské bytosti jako „tvora nadaného rozumem, jehož nejvyšší důstojnost je v intelektu; jako svobodné individuum v osobním vztahu $\mathrm{k}$ Bohu, jehož nejvyšším právem je dobrovolné podřízení se Božímu zákonu; jako hříšného a zranitelného tvora povolaného žít k Božímu obrazu a podle Boží podoby a ke svobodě milosti, jejíž nejvyšší dokonalost spočívá v lásce“. ${ }^{14}$ Maritain navázal na učení Tomáše Akvinského a aplikací metodologického kritéria „distinguer pour unir“ (rozlišuj, abys sjednotil, tj. rozlišuj za účelem sjednocení na vyšší úrovni) chápe člověka v jeho základní bytostní jednotě, ale rozlišuje jej ve dvou stupních - jako individuum a jako osobu. Toto rozlišení se stává jádrem jeho filozofie výchovy. Lidská osoba a její plná realizace se stává středobodem edukace, jíž je integrální výchova. Přijetím tomistického paradigmatu definuje Maritain člověka jako individuální osobu, subjekt, který sám sebe vlastní skrze rozum a vưli a ve kterém je př́tomen imanentní, vitální princip života (vnitřní duchovní princip), otevřený vůči vnějšímu světu. Člověk je úplný a nezávislý, je integrálním bytím. ${ }^{15}$ Maritainova filozofie výchovy je založena na tomismu, který uznává integrální roli duchovních a metafyzických dimenzí osoby. Zatímco teocentrický humanismus je světem osoby, antropocentrický humanismus je světem individua. Člověk jako osoba přesahuje společnost a stát, jako individuum je společnosti podřízen. ${ }^{16}$ Lidská bytost tedy už není jen fyzické individuum, ale osobou se svobodnou vưlí, jež je odpovědnou za své činy.

10 Philippe CHENAUX, Maritain na úsvitu třetího tisíciletí, Salve 2/2006, s. 14.

11 Tamtéž, s. 13

12 HREHOVÁ, Morálna filozofia Jacquesa Maritaina..., s. 27.

13 Marek WIESENGANGER, Perspektívy filozofie výchovy podla Jacquesa Maritaina, Acta Fac. Paed. Univ. Tyrnaviensis, Ser. D 15/2011, s. 41.

14 Jacques MARITAIN, The Education of Man: The Educational Philosophy of Jacques Maritain, vydáno Donaldem a Idellou Gallagherovými, Notre Dame, Ind: Notre Dame University Press, 1963, s. 7.

15 Tamtéž, s. 42

16 Joaquim D'SOUZA, Education to Freedom: Don Bosco and Jacques Maritain in Tandem?, Journal of Philosophy and Education 1/2006, s. 6 . 
Dokonalé činy jsou iniciovány milostí Boží. ${ }^{17}$

Ústředním bodem Maritainovy filozofie výchovy je tedy osoba a její plná realizace. Základ jeho filozofie výchovy se pokusíme dále definovat na základě odpovědí na následující otázky: „Co je to výchova a vzdělávání?“, „Jaké jsou cíle výchovy a vzdělávání?“, „Jaké jsou základní dispozice žáka?" a „Jakou roli ve výchovně-vzdělávacím procesu sehrává učitel?" Maritain definuje výchovu a vzdělávání jako „doprovázení člověka $\mathrm{v}$ dynamickém růstu, během něhož se formuje $\mathrm{v}$ míře lidské osoby současně s tím, jak se k němu dostává duchovní dědictví národa a civilizace, ke kterým patří, stejně jako světské dědictví generací, které tak tímto způsobem může být zachováno. "18 Vzdělávání je „probouzením člověka“, „stáváním se tím, kým jsme“, „uměním, kde každý se může stát uměleckým dílem“. 19

\section{Cíle výchovy a vzdělávání}

Maritain, inspirován slavným citátem řeckého básníka Pindara „Uč se, čím jsi a bud” tím“, formuluje hlavní cíl edukace jako utváření člověka a usměrňování rostoucího dynamismu, jímž člověk utvárí sebe sama. ${ }^{20}$ Prvním cílem výchovy a vzdělávání je nabytí vnitřní a duchovní svobody; osvobození skrze znalost, moudrost, dobrou vůli a lásku. Stávání se svobodným, stávání se sám sebou, stávání se člověkem. ${ }^{21}$ Křest’anská výchova musí dětem, mladým lidem a dospělým umožnit poznat, kým jsou, dosáhnout své skutečné podoby dle obrazu Božího a stát se autenticky lidskými, aby „dosáhli jednoty víry a poznání Syna Božího, a tak dosáhli zralého lidství, měřeno mírou Kristovy plnosti“ (Ef 4,13). Druhým cílem edukace je stávání se občanem, plnohodnotným členem společnosti. Podle Maritaina by škola měla primárně naučit žáky myslet a rozvíjet jejich vnitřní intelektuální schopnosti. ${ }^{22}$ Měla by zajistit dosažení osobní a společenské plnosti svých absolventů, a stát se tak přípravou k životu v demokratické společnosti.

Maritain utvářel svoji filozofii výchovy na základě konfrontace s omyly tehdejších pedagogických teorií. Tyto myšlenky byly prvně publikovány v knize Education at the Crossroads (Výchova na rozcestí) v kapitole „Omyly ve vzdělávání. ${ }^{23}$ První cíl výchovy a vzdělávání formuloval v protikladu k perspektivě ateleologičnosti (popírání cílů edukace), pseudoteleologičnosti (nesprávnosti myšlenek týkajících se cíle, napřr. redukce osoby na celek fyzických, biologických a psychologických fenoménů) a pragmatismu (absence rozměru kontemplace a myšlenky zdokonalování osoby jako osoby). Druhý cíl výchovy a vzdělávání stanovil na základě kritické reflexe sociologismu (osoba jako funkce vlastních cílů společnosti), intelektualismu (zaměření na encyklopedické znalosti a předčasná specializace), voluntarismu (zaměření na izolovanou výchovu vůle a citů bez důrazu na rozvoj rozumu) a pandidaktismu (přesvědčení, že všemu se dá naučit). ${ }^{24}$

\section{Role žáka/studenta a učitele}

Podle Maritaina je žák/student se svojí intelektuální schopností primární agens, hybná síla procesu vzdělávání. Na prvním místě stojí vnitřní vitální princip, primární dynamický faktor, působící

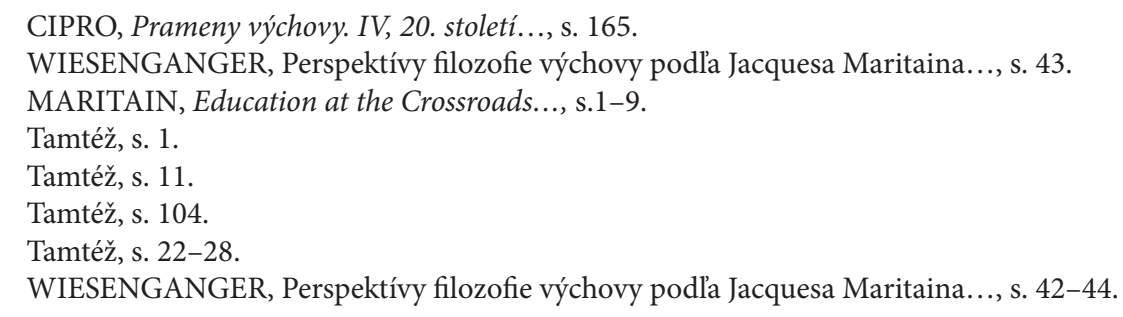


v učícím se žákovi/studentovi. ${ }^{25}$ Maritain uvádí pět přirozených dispozic, jež se mají v žákovi/ studentovi rozvíjet: láska $\mathrm{k}$ pravdě, láska $\mathrm{k}$ dobru a spravedlnosti, prostota a otevřenost ducha, úcta k práci a smysl pro spolupráci. ${ }^{26}$ Prvním pramenem poznání je podle Maritaina intelektuální intuice, vedená láskou k pravdě (být otevřen ke světlu, per amorem cognoscimus - poznáváme láskou). ${ }^{27} \mathrm{Od}$ žáka/studenta se očekává, že bude odhalovat, co znamená prožít kvalitní autentický život, a že si zároveň sám bude vytvářet kritéria autentičnosti, tj. bude sám sobě vychovatelem a sám před sebou vychovávaným. ${ }^{28}$

Učitel představuje ve výchovně-vzdělávacím procesu druhý dynamický faktor. Jeho úloha spočívá v intelektuálním vedení žáka/studenta, povzbuzování jeho intelektuálních dispozic s absolutním respektem vưči jeho „vitálnímu vnitřnímu principu. “ Učitelovo umění spočívá v tom, že napodobuje cesty, jimiž postupuje přirozená inteligence ve svých vlastních operacích. ${ }^{29}$ Podle Maritaina by se umění vychovávat mělo přirovnávat k lékařskému umění: „Lékařství se zabývá živou bytostí, organismem, který obsahuje vnitřní vitalitu a vnitřní princip zdraví. Jinak řečeno, lékařství je ars cooperativa naturae, služebné umění, umění ve službě přirozenosti. Totéž platí o výchově. “30 Učitel je facilitátorem a zároveň umělcem, který inspiruje a „osvěcuje“. Maritainovy metafory lékaře a umělce zároveň odkazují na skutečnost, že učitel využívá ve své práci vědecké i umělecké metody. Podle Maritaina úspěšnost edukace závisí spíše na osobnosti učitele než na volbě metod a organizačních forem. Učitel a žák/student jsou si ve své přirozenosti podobni („analogičtí“). Dynamickými faktory výuky se stávají přirozená aktivita ducha žáka a intelektuální vedení učitelovo spolu s vnitřní touhou žáka/studenta (primární dynamický faktor a impuls), který představuje hlavní působivou sílu. ${ }^{31}$ Výsledkem edukace má být člověk, který „existuje rád“, nebot pocituje respekt vưči své osobě, je začleněný do lidského společenství, které ho neutlačuje, a může naplňovat vlastní aspirace přiblížení se pravdě a vlastní nutkání k dobru. ${ }^{32}$ Maritain stanovuje čtyři základní normy pro učitele: osvobozování dobrých energií jako nejlepší prostředek k potlačení špatných, zaměření pozornosti na vnitřní hloubku osoby žáka a jejího předvědomého duchovního mechanismu, zajištění vnitřní jednoty osoby žáka, osvobozování žákovy inteligence, nikoli její přetěžování nepřiměřenými požadavky. ${ }^{33}$

\section{Základiní principy edukace}

Marek Wiesenganger ve své studii Perspektivy filosofie výchovy podle Jacquesa Maritaina vymezuje autorovy tř̀i základní principy edukace: personální princip a integrální edukaci; výchovu a vzdělávání jako stávání se svobodným a princip pluralismu. Je potřeba rozvíjet personalitu i individualitu, prioritu má však princip personality. Podle Maritaina je koncepce individuální osoby základem integrální výchovy. Druhý princip představuje stávání se svobodným skrze výchovu, vzdělání a kulturu. Nejedná se o svobodu ve smyslu volby. Jedná se o osvobozování konstitutivních principů vnitřního života (poznávání, láska), ale i osvobozování na úrovni jednoty vnitřního

\footnotetext{
MARITAIN, Education at the Crossroads..., s. 31.

Tamtéž, s. 36-38.

Jiř́ VAČKÁŘ, Jacques Maritain (18. 11. 1882 - 28. 4. 1973) - výročí, Prostor 25/1993, s. 130.

WIESENGANGER, Perspektívy filozofie výchovy podla Jacquesa Maritaina..., s. 55.

CIPRO, Prameny výchovy. IV, 20. století..., s. 165.

MARITAIN, Education at the Crossroads..., s. 30.

Miroslav CIPRO, Pedagogické směry 20. století v kapitalistických zemích, Praha: SPN, 1966, s. 300.

(c) Andrej RAJSKÝ, Univerzitné vzdelavanie v koncepte integrálneho humanizmu Jacquesa Maritaina (on-line), dostupné na: http://pdf. truni.sk/zborniky/evsuv-2004/sekcia2/Rajsky.pdf, citováno dne 19. 5. 2018.

33 Jacques MARITAIN, Pour une philosophie de l'education, Paris: Fayard, 1969, s. 53-62.
} 
života. ${ }^{34}$ Třetí zásada, princip plurality, je jedním z aspektů demokracie, na níž jsou svobodná výchova a vzdělávání postaveny. $\mathrm{Na}$ úrovni jednotlivce představuje pluralitní princip hledání a uskutečnění cesty osobní jedinečnosti, na úrovni společnosti odhalování a realizaci cest vzájemného spolužití. V knize Pour une Philosophie de l'Éducation dospěl Maritain k nutnosti zavedení jakéhosi společného kréda demokracie a edukace: krédo lidské a dočasné a krédo filozofické nebo náboženské. Spojení pluralitního principu (úcty ke svobodě) a principu jednoty (hledání pravdy) je dle Maritaina uskutečňováno v koncepci integrálního humanismu, který umožňuje člověku rozvíjet jeho metafyzickou důstojnost na dialektické ose „odněkud-někam“. ${ }^{35}$

\section{Aktuální podiněty}

Konfrontace s tehdejšími pedagogickými teoriemi vzbudila Maritainův zájem o problematiku výchovy a vzdělávání v nejrůznějších oblastech. S ohledem na limitovaný rozsah tohoto článku se zaměříme jen na některá témata odpovídající aktuálním potřebám současného školství. Jedná se o liberální vzdělávání a humanitní předměty (zejména výuku literatury), otázku specializace v jednotlivých stupních vzdělávání, pedagogiku volného času, celoživotní vzdělávání, etickou a náboženskou výchovu.

\section{Liberální vzdělávání, problematika specializace}

Jacques Maritain byl propagátorem liberálního vzdělávání (studia humanitatis a artes liberales), jehož cílem je dosažení plného a hodnotného lidského života spolu s rozvojem kultury a občanského ducha. Maritain prosazuje princip spojení jednoty věcného obsahu učiva (faktologicky nesporné osnovy) a diferenciace ideového základu vyučování. Studijní předměty rozděluje na tzv. „předliberální, tj. jakýsi základ všeobecného vzdělání (gramatika, logika, jazyky a disciplíny historické) a „liberální“, tj. obecně vzdělávací. Sem přináleží trivium (rétorika, literatura s poezií a hudba s krásnými uměními) a quadrivium (matematika, fyzika s př́rodními vědami, filozofie a morálka). Střední vzdělávání by se dle něho mělo věnovat výuce humanitních a přírodních věd se zaměřením na procvičení logického a racionálního uvažování. Jedná se o studium obecně vzdělávacích předmětů zacílené na obsah a přípravu k lidské práci a užívání volného času (bez předčasné specializace). ${ }^{36}$ Základní a střední školství by mělo zabezpečit především výchovu pro život. Předčasná specializace brání plnému rozvoji lidských potencialit, je nástrojem dehumanizace. Především středoškolské studijní programy by se podle Maritaina měly částečně vzdát funkcionální vize rychlého začlenění studentů do profesionálního světa práce a věnovat větší pozornost formování člověka jako kulturní osobnosti. ${ }^{37}$ Maritain kritizuje intelektualismus své doby kvưli opouštění univerzálních hodnot a orientaci spíše na vědeckou a technickou specializaci. Na středoškolské a předuniverzitní úrovni má výchova studentům poskytovat všeobecné vzdělání a vést $\mathrm{k}$ formování studenta ve skutečného člověka. Přirozené nadání, posílené všeobecným vzděláním, člověka podle Maritaina osvobozuje a rozšiřuje jeho ducha. ${ }^{38}$ Univerzita by měla být zaměřena na universum, veškerenstvo věcí, a otevřena pro celek. $Z$ tohoto důvodu zaujímá v rámci univerzitního studia naprosto výsadní postavení

34 Tamtéž, s. 46

35 RAJSKÝ, Univerzitné vzdelavanie..., s.1.

36 CIPRO, Prameny výchovy. IV, 20. století..., s. 174.

37 RAJSKÝ, Univerzitné vzdelavanie..., s. 3.

38 CIPRO, Prameny výchovy. IV, 20. století..., s. 172. 
filozofie, která by měla zahrnovat epistemologii, filozofii př́rody, etiku a politickou a sociální filozofii. Z pohledu Maritaina specializace a profesionalizace ve vlastním slova smyslu přináleží vyšším odborným školám a univerzitám.

\section{Výuka literatury (the great books)}

Jacques Maritain vyzývá $\mathrm{k}$ většímu zaměření na formování člověka jako kulturní osobnosti prostřednictvím humanitních předmětů a umění, schopných překládat všelidské hodnoty a disponovat člověka pro život ducha, otevírat jej přesahu. Reflexe umění prochází celým Maritainovým filozofickým dílem. $\mathrm{V}$ díle Creative Intuition in Art and Poetry (Tvořivá intuice v umění a poezii, 1955) Maritain analyzuje vztah umění a krásy, která má „působit harmonickou duchovní ra-

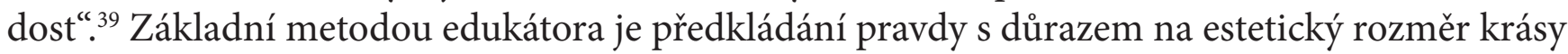
a morální rozměr dobra. Pravda je zachycena v literárních dílech světového písemnictví, důležitou roli sehrává tedy hermeneutika velkých literárních děl. Maritain spolu s Robertem Hutchinsem a Mortimerem Adlerem podporoval začlenění četby děl velkých klasiků západní literatury do vysokoškolského studijního programu ${ }^{40}$ Počátky amerického hnutí „Great Books“ jsou spojeny s Chicagskou univerzitou, dnes je „The Great Books Programme“ součástí nabídky studijních předmětů některých univerzit v USA, Kanadě a Evropě. Program je zaměřen na četbu a interpretaci významných literárních děl nejenom západní civilizace. Podle Maritaina se četbou Homéra, Sofokla, Marca Aurelia, Danteho, Cervantese, Shakespeara, Racina, Goetha, Dostojevského aj. naplní mysl studentů „caritas humani generis“. Studiem děl klasiků se zvláštním zřetelem k literatuře a kultuře antické se studenti vracejí $\mathrm{k}$ tématu člověka a vážných existenciálních otázek. Je to jeden $\mathrm{z}$ nejlepších prostředků $\mathrm{k}$ pochopení esence lidství, fenoménu heroismu lásky a nejvyšších hodnot bytí. Jedná se o účinný nástroj všestranné kultivace lidského ducha v rovině intelektuální i mravní. Studovat etiku skrze díla klasiků se jeví být mnohem efektivnějším než samotná teoretická studia tohoto předmětu. Četba přináší nejenom poznání pravdy, ale i prožitek pravdy a krásy. Estetická zkušenost je dalším poznáním, které se v díle realizuje. Maritain jej charakterizuje jako poznání zvláštního druhu, tzv. poznání pomocí sourodosti. ${ }^{41}$ Poznání sourodostí čili per connaturalitatem je poznání cestou vcítění či náklonnosti, rezonance v subjektu. ${ }^{42}$ Západní civilizace by skrze četbu klasiků mohla znovuobjevit své kořeny a křestanské principy své kultury. Podle Maritaina by střední škola měla rozvíjet svobodná umění a univerzita pak v rámci víceleté filozofie též studium řeckých a latinských klasiků včetně volitelného předmětu zaměřeného na studium kulturního a intelektuálního dědictví západní civilizace v podobě kánonu západní kultury (The Great Books).

\section{Pedagogika volného času, celoživotní vzdělávání}

Při vymezení struktury školního učebního plánu rozlišuje Maritain „hry“a „studium“. Do „her“ řadí kromě sportu a tělesné výchovy i řemeslné manuální činnosti. Součástí je i široká paleta různých praktických činností, které spiše než předmětem formálního vzdělávání mají být hravou aktivitou zájmovou. ${ }^{43}$ Maritainův zájem byl zacílen významným způsobem na volnočasové

39 VAČKÁ̌̆, Jacques Maritain..., s. 131.

40 Gerald L. GUTEK, Jacques Maritain and John Dewey on Education: A Reconsideration, Educational Horizons 4/2005, s. 249.

41 Jacques MARITAIN, Odpovědnost umělce, Praha: Triáda, 2011, s. 99.

42 Klára JELÍNKOVÁ, Umění ve filozofii Jacquesa Maritaina, Salve 2/2006, s. 30.

43 CIPRO, Prameny výchovy. IV, 20. století..., s. 174. 
aktivity. Jejich význam spatřoval ve svobodě a radostné spontánnosti, kterou dítě při nich zažívá. Paradoxem zůstává skutečnost, že mimoškolní sféra zahrnující volnočasové aktivity ovlivňuje žáka „činností, která je ve svém výsledku důležitější než samotná školní výuka“" ${ }^{44}$ Podle Maritaina jsou věci, kterým se nelze naučit v žádné škole ani kurzu. Přitom se jedná o zásadní záležitosti života, jako např. navázání vztahu přátelství a lásky, dosažení moudrosti. Nejsou záležitostí výuky či tréninku, jsou darem a svobodou. V knize Education at the Crossroads Maritain předpovídá, že „problém volného času bude zásadním problémem světa zítřka“ ${ }^{45}$ Pedagogika volného času představuje velmi vhodný nástroj pro růst toho, co je v člověku nejlidštější. Podle Maritaina výchova a vzdělávání nekončí za branami škol, ale „pokračuje až do smrti“. Pro celoživotní vzdělávání se Maritain vyslovil svojí kritikou tradovaného názoru, že celý proces formování lidské bytosti lze vtěsnat do mikrokosmu školní výchovy: „jako velké továrny, jejíž vstupní branou vchází malé dítě jako surovina a východem pak odchází mladík v lesku svých dvaceti let jako člověk štastně vyrobený “ ${ }^{46}$

\section{Etická výchova}

Maritainovy názory na morálku jsou shrnuty v jeho pedagogicko-didaktickém díle Devět lekcí o základních pojmech morální filozofie (Neuf Leçons sur les Notions Premières de la Philosophie Morale, 1951), ve kterém jsou zesystematizovány jeho myšlenky navazující na Aristotela a Tomáše Akvinského. ${ }^{47}$ Je-li podle Maritaina umění pravým vedením a zhotovováním, etika je pravou kvalitou konání, jak uvádí v díle Umění a scholastika (Art et scolastique, 1920). ${ }^{48}$ Pilířem kodexu morálky je podle něho Desatero Božích přikázání, v jehož obsahu je zahrnut celý přirozený zákon, který je zároveň zákonem univerzálním. ${ }^{49}$ Člověk musí být lidským především ve smyslu mravním. Maritain zdo̊razňuje morální výchovu žáka/studenta se zřetelem k rozvoji „caritas humani generis“. Vnitřní svobody musí člověk nabýt v kontextu společného dobra. Jak uvádí autor $\mathrm{v}$ knize The Education of Man: The Educational Philosophy of Jacques Maritain (Výchova člověka: Filozofie výchovy Jacquesa Maritaina), primární odpovědnost za mravní výchovu dítěte nese rodina. Odpovědnost školy spočívá v intelektuálním rozvoji žáka/studenta, ve vzdělávání jeho praktického rozumu, nikoli v cílené výchově vưle a v př́mém rozvoji mravních ctností. ${ }^{0}$ Podle Maritaina „morálka je louhována v inteligenci“ a cílem vzdělávání je v žákovi probudit morální inteligenci. ${ }^{51}$ Maritain je přesvědčen, že edukace patří do oblasti etiky a praktické moudrosti; samotná výchova je etickým uměním. ${ }^{52}$

\section{Náboženská výchova}

Vrcholnou formou mravní výchovy je výchova náboženská. Maritainova filozofie výchovy je edukativní koncepcí, jež integruje všechny dimenze lidské osoby včetně člověka jako Homo religiosus, tj. jako duchovně-náboženskou bytost. Zaměřuje se na lidskou osobu jako celek. Usiluje o reintegraci osoby s Tvůrcem a integraci všech lidí ve společenství či společnosti, sdílejíc

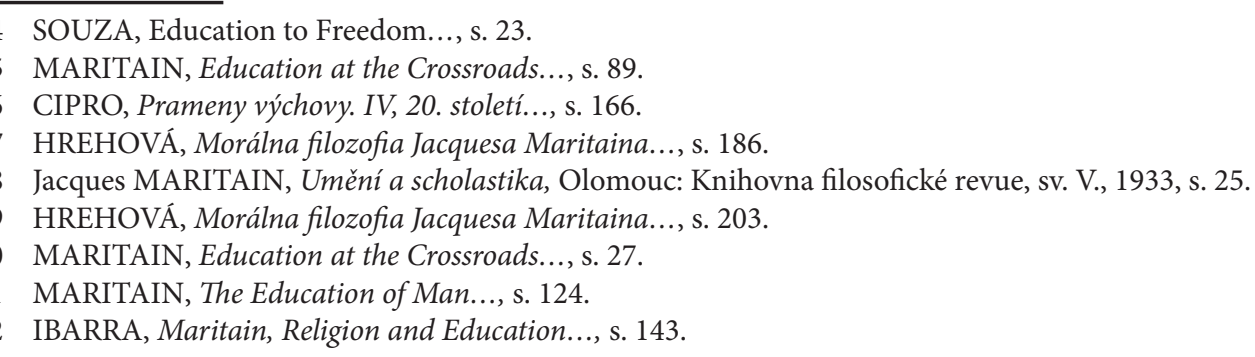


společnou víru v Boha a společný zájem o blaho lidstva. ${ }^{53}$ Maritain nebyl teolog, ale filozof. Když navrhoval svoje pojetí filozofie výchovy, koncepce křest’anské výchovy ještě nedosahovala dnešní úrovně propracovanosti. Maritain, inspirován učením Tomáše Akvinského, vybudoval svoji filozofii na tezi, že „člověk je schopen s jistotou poznat pravdu“ ${ }^{54}$ Celým svým dílem ukazoval prioritu duchovních a metafyzických hodnot v životě člověka a horoval pro novou integrálně lidskou civilizaci, nacházející své opravdové duchovní zdroje v inspiraci evangeliem a v sebeuvědomění v duchu evangelia. ${ }^{55}$ Člověka svojí současnosti označuje za křestana, více či méně sekularizovaného. ${ }^{56}$ Každý (včetně materialisty a ateisty) je de facto křest̉an ve smyslu etickém a kulturním, je-li jeho morálka stejně lidská jako morálka Bible. ${ }^{57}$ Jeho kultura je kultura křestanská. Bez základních znalostí z oblasti teologie nelze plně pochopit tradiční, ani moderní západní kulturu, ani historii středověku a novověku. Důležitým mezníkem v Maritainových úvahách o náboženské výchově byla přednáška na Kent School v roce 1955, kterou Yalská univerzita uveřejnila $\mathrm{v}$ publikaci The Christian Idea of Education. Tato přednáška se později stala součástí knihy Pour une Philosophie de l'Ėducation a The Education of Man: The Educational Philosophy of Jacques Maritain. Autor se zde zabývá základními rysy křestanské výchovy. Náboženská výchova směřuje podle Maritaina k dosažení duchovní svobody a skutečné podoby osoby dle obrazu Božího. Hlavním cílem křestanské výchovy je výchova ducha, myšlení a svědomí. Neznamená jen získávání znalostí a vědomostí, ale zahrnuje i hodnotovou orientaci, je zároveň výchovou mravní. Maritain klade v počátečních fázích výchovy důraz na oživení rozumu a mravní síly. ${ }^{58}$ Náboženská výchova by měla posilovat spiritualitu ve smyslu duchovní cesty a sebeobjevování a nasměřovat žáky/studenty $\mathrm{k}$ hledání smyslu jejich života. Sebezdokonalení člověka přichází skrze lásku a je to nakonec Boží láska, jež transformuje člověka do osoby. V knize Integrální humanismus se Maritain vyslovuje pro nalezení správného místa pro křestłanskou výuku ve struktuře školství, nebot’ náboženství tvoří potřebnou součást školní výuky. ${ }^{59}$ Podle Maritaina má dítě právo, aby bylo vyzbrojeno náboženskými znalostmi jako jinými znalostmi podstatnými pro život člověka. Vedle podpory náboženské výchovy na církevních školách usiloval na ostatních školách o vzdělávání s náboženským zaměřením v humanitních vědách skrze jednotné osnovy a fakultativní náboženskou výchovu. Obsah všech těchto předmětů je třeba spojovat s duchem křestanství. Seznámení s obsahem Bible by mělo být součástí vzdělávání na všech typech škol. Náboženská výchova nemá být uzavřena sama do sebe, ale má docházet k její širší integraci do intelektuálních zájmů a osobního života žáků/studentů. Maritain doporučuje dokonce účast na liturgickém životě a scházení se žáků/studentů např. k četbě evangelia. ${ }^{60}$ Podle Maritaina není žádný důvod vyloučit výuku teologie z nabídky jakéhokoli univerzitního studia. Teologické předměty by měly zůstat předmětem svobodné volby. ${ }^{61}$ Studentům ateistického zaměření by mělo být umožněno např. studium předmětu religionistika. Jak uvádí Maritain v knize Education at the Crossroads (Výchova na rozcestí), „pokud i tato nabídka nenajde mezi studenty odezvu, bude jim dovoleno k jejich vlastní spokojenosti zůstat

53 Tamtéž, s. 120.

54 Ján LETZ, Novotomistické metafyziky: Křest’anská filozofia 20. storočia a jej perspektívy, Trnava: Typi Universitatis Tyrnaviensis, 2007, s. 40 .

55 MARITAIN, Integrální humanismus..., s. 78.

56 MARITAIN, Education at the Crossroads..., s. 6.

57 CIPRO, Prameny výchovy. IV, 20. století..., s. 159.

58 IBARRA, Maritain, Religion and Education..., s. 133.

59 MARITAIN, Integrální humanismus..., s. 172.

60 CIPRO, Prameny výchovy. IV, 20. století..., s. 176.

61 RAJSKÝ, Univerzitné vzdelavanie..., s. 6. 
nedovzdělanými“ ${ }^{62}$ Úhelným kamenem studií na teologických fakultách musí být dle Maritaina teologie a filozofie. Zároveň se vyslovuje pro zavedení dalšího doplňku vysokoškolského vzdělávání - tzv. center spirituality, středisek pokoje, které by v duchu evropských tradic exercicií dávaly studentům prostor $\mathrm{k}$ prohloubení jejich vlastní mystické vertikality. ${ }^{63}$

\section{6. Život modlitby, mystika}

Karel Šprunk, novotomistický filozof maritainovské orientace, předseda České společnosti Jacquesa Maritaina (založené v roce 1993), charakterizoval Maritainovo úsilí těmito slovy: „Jacques Maritain hledá cestu, jak vše pronikat světlem evangelia, jak rozvíjet všechny hodnoty lidství a přitom plně rozvíjet život, který je darem Ducha svatého “. ${ }^{64}$ Podle Maritaina bude svět plně humanizován jedině v Kristu. Jak uvedl Tomáš Akvinský, „Kristovo lidství je svrchovaně přizpůsobenou pedagogikou, která vede $\mathrm{k}$ jeho božství' ${ }^{65}$ Člověk naplňuje svůj lidský úděl jedině v Kristu Bohočlověku. Ve své poslední knize La Paysan de la Garonne (Garonský sedlák, 1966) Maritain uvádí, že v celostním pojetí osoby nejvíce záleží na životě modlitby a jednotě s Bohem. ${ }^{66}$ Maritain a jeho manželka Raïssa žili vnitřní modlitbou ${ }^{67} \mathrm{~V}$ knize Láska a přátelství (český překlad z Cercle d'Ėtudes Jacques et Raïssa Maritain, 1973) označuje Maritain milost kontemplace za laskavé a živoucí vstupování do stavů Ježíšových. ${ }^{68}$ Modlitbu pak ve světě, jak ho stvořil Bůh, považuje za nutnost: „Jestliže se nemodlíme, nemůžeme růst v křestanském životě ani dostávat všechny dobré věci, pravou bratrskou lásku, vnitřní pokoj a radost a Jobovo hnojiště a jeho červy - věci, jimiž se zde na zemi vstupuje do věčného života“ ${ }^{69}$ Mystická zkušenost je pak zkušeností „zmocňující se absolutna“ ${ }^{70}$ Michael Novak označil Maritaina za „nejsvatějšího filozofa, kterého ve svém životě poznal“ “. ${ }^{11}$ Maritain v knize Integrální humanismus předpokládá, že „uvědomění časného poslání křestana vyvolá nějaký nový styl svatosti, jejž možno vyznačit především jako svatost a posvěcení života světského“"72 Maritain samotný se svým životem stává př́íkladem profánní svatosti. Je potřeba stát se „blázny ve víře“, vstoupit do stavu pošetilé lásky k Bohu. ${ }^{73}$ Donald A. Gallagher ve své studii Reflections of Three Philosophers uvádí, jak Maritain v dopise kongregaci Malých bratř́ Ježíšových žertovně před svým přijetím navrhuje své nové jméno „Don Quijote od Svatého Tomáše“.74

\section{Maritainova Novotomistická pedagogika}

Současná multikulturní, globální společnost je stále postižena relativismem, matením pojmů a zmatením hodnot, jak tyto neduhy své doby pojmenoval Maritain již v díle Integrální humanismus. Jeho varování před zvěcněním člověka, konzumerismem, egoistickou orientací a technokracií

\footnotetext{
MARITAIN, Education at the Crossroads..., s. 75.

3 RAJSKÝ, Univerzitné vzdelavanie..., s. 7.

4 Karel ŠPRUNK, Rozlišovat ale neoddělovat - rozhovor s Karlem Šprunkem, Salve 2/2006, s. 47.

65 Jean Pierre TORRELL, Svatý Tomáš Akvinský, osoba a dílo, Praha: Krystal OP, 2017, s. 205.

6 Srov. HREHOVÁ, Morálna filozofia Jacquesa Maritaina..., s. 187.

67 Gerald A. McCOOL, S.J., From Unity to Pluralism: The Internal Evolution of Thomism, New York: Fordham University Press, 2002, s. 116.

68 Jacques MARITAIN, Láska a prátelství, Praha: Krystal OP, 2005, s. 22.

69 Raïssa a Jacques MARITAINOVI, Stavy lidstva a svatosti, Praha: Krystal OP, 2011, s. 73.

70 Jacques MARITAIN, Přirozená mystická zkušenost a prázdnota, Salve 2/2006, s. 97.

71 Michael NOVAK, On Cultivating Liberty: Reflections on Moral Ecology, Lanham: Rowman \& Littlefield Publishers, Inc., 1999 , s. 186.

72 MARITAIN, Integrální humanismus..., s. 120.

73 MARITAIN, Láska a prátelství..., s. 19.

74 (C) Donald A. GALLAGHER, Recollections of Three Thinkers: Adler, Simon, and Maritain, dostupné na: https://maritain.nd.edu/ama/ Torre/Torre04.pdf, citováno dne 20. 5. 2018, s. 29.
} 
je více než aktuální, stáváme se jejich očitými svědky. Dnešní doba svědčí o nenaplněnosti konceptu antropocentrického humanismu v míre odpovídající potřebám společnosti a jednotlivce 21. století. Je žrejmé, že současná společnost se musí začít angažovat pro člověka-osobu, která není součástí úzce utilitárního, ale vesmírného řádu. Toto je jeden z největších odkazů celého Maritainova myšlení a personalistická antropologie se stává výzvou pro současnou pedagogiku. Křestanství v tomto smyslu v naší kultuře přináleží naprosto výsadní postavení. Maritainovu filozofii výchovy lze přriřadit $\mathrm{k}$ neotomistické pedagogice, křestanskému (integrálnímu) personalismu, holistické (celostní) edukační koncepci, perennialistické výchovně-vzdělávací teorii a pedagogice hodnot (pedagogice kultury).

Maritainovu filozofii výchovy nelze oddělit od jeho širší filozofické orientace, která se odvozuje od Tomáše Akvinského, Aristotela, neoscholastiky (např. Joaõ Poinsot), stejně jako od křestanských autorů, jakými jsou sv. Augustin a sv. Jan od Křriže. Maritain nahližel vzdělávání z perspektivy neotomistické filozofie (dalšími představiteli jsou např. W. Cunningham, E. Smith, M. Casotti). Maritainovy knihy Stupně poznání (Les dégres du savoir, 1932) a Filozofie př́rody (La philosophie de la nature, 1935) patř́ mezi největší projevy tomismu ve 20. století. V oblasti křestanské epistemologie lze spatřovat jeden z největších př́nosů Maritaina pro pedagogiku dnešní doby. Maritain díky své obrovské erudovanosti v oblasti reflexe společenských a politických otázek, jíž dokládají napr. jeho díla Integrální humanismus (Humanisme Integral, 1936, 2. vydání 1946), Křestanství a demokracie (Christianisme et Démocratie, 1943) a Člověk a stát (L'Homme et l'Ėtat, 1953; Man and the State, 1951), měl výsostné předpoklady pro reflexi stavu současného školství a úrovně vzdělanosti. Intenzivně se začal věnovat publikační činnosti v oblasti pedagogiky od roku 1943 v souvislosti s přednáškovou činností „Terry Lectures“ na Yalské univerzitě. Jeho nahližení na vzdělávání z perspektivy novotomistické filozofie a přesvědčení o užitečnosti aplikace tomistických principů do vzdělávacích institucí (včetně necírkevních) přispělo k etablování novotomismu jako jednoho z filozofických proudů v moderním myšlení o výchově. Pro studium Maritainovy tomistické pedagogiky má klíčový význam kapitola „Tomistické názory na výchovu“ jako součást textu knih Pour une Philosophie de l'Éducation a The Education of Man: The Educational Philosophy of Jacques Maritain.

\section{Maritainova personalistická, integrální edulkace}

Jako představitel neotomistického personalismu (např. spolu s E. Gilsonem) předkládá personalistický pohled na výchovu a vzdělání s prioritou principu personality. Ústř̌edním bodem Maritainova myšlení bylo rozlišení individua a osoby, jež sehrává fundamentální roli v jeho filozofii výchovy a vlastní pedagogické praxi. Středobodem se stává osoba ve svém personálním rozměru svobodného sebevlastnění a sebeurčení prostřednictvím rozumu a vůle. Koncepce individuální osoby je základem integrální edukace pro uskutečnění integrálního humanismu, který představuje překonání principu individualismu i totalitarismu/kolektivismu principem personalistické civilizace. ${ }^{75} \mathrm{~V}$ závěru knihy Education at the Crossroads Maritain uvedl, že „americké školství se nachází na křižovatce - potřebuje osvobodit od instrumentalismu pragmatické filozofie a nahradit ji hluboce personalistickým integrálním humanismem".76 Maritainem vrcholí novotomistická orientace integrálního personalismu. Integrální př́stup napomáhá rozvoji žáka na několika úrovních: vychovává jej jako celek, usiluje o jeho reintegraci s Tvůrcem a o jeho integraci v rámci

75 WIESENGANGER, Perspektívy filozofie výchovy..., s. 45.

76 MARITAIN, Education at the Crossroads..., s. 118. 
společenství a společnosti. Jak dokládá text tohoto článku, Maritainovo pedagogické dílo je plodem autorova hledání integrální neredukující podoby edukace jako procesu a zároveň jako organizovaného systému vzdělávání. ${ }^{77}$ Cílem integrální výchovy je osvobození jedince skrze vyšší poznání a moudrost, dobrou vůli a lásku; naplnění základního poslání člověka být naplno sám sebou. Podle Jána Letze se díky Maritainově integrálnímu personalistickému principu mohl jeho personalismus stát životním principem moderní politické činnosti. ${ }^{78}$ Domníváme se, že podobnou roli by při znalosti Maritainova pedagogického odkazu mohl sehrát i v oblasti školství.

\section{Maritainův holistický a perennialistický př́istup}

Jedním z nejvýraznějších rysů Maritainovy výchovně-vzdělávací koncepce je jeho holistický př́stup, zaměřující výchovu a vzdělání na celou osobu. Spolu s Thomasem Mertonem patřil Maritain mezi první propagátory tohoto prŕistupu v pedagogice. ${ }^{79}$ Maritain byl zastáncem perennialistické edukační teorie, která vychází z předpokladu, že člověku je jeho přirozeností dána vlastní potencionalita vědět a inklinovat $\mathrm{k}$ nalezení pravdy. Tato schopnost se rozvíjí přiváděním žáků ke kolektivní zkušenosti lidstva skrze kulturní dědictví, obsažené v dílech umění, literatury, filozofie a vědy. Maritain je zaměřen na vzdělanostní obsah výchovy a předávání „hodnotové paměti předkư“. Jde mu o systém hodnot lidského ducha a srdce. V tomto smyslu jej lze zahrnout mezi představitele pedagogiky hodnot (pedagogiky kultury). Maritainovo pojetí integrálního humanismu navazuje na antickou tradici humanismu. Ve shodě s interpretací Wernera Jaegera v jeho díle Paideia. Ideály řecké kultury (Paideia. Die Formung Des Griechischen Menschen, 1933) vztahuje pedagogický proces k ideálům pravdy, krásy a dobra. Paideia představuje proces výchovy, ve kterém je smyslem a cílem imperativ: „Poznej sebe sama“. Vycházíme-li z textů Maritainových pedagogických prací, autor by nepochybně podpořil text manifestu „Paideia Proposal“ Mortimera J. Adlera z roku 1982, předkládající reformu amerického státního školství. Návrh k paidei v současné filozofii výchovy představuje myšlenkový odkaz Agustína Basave Fernándeze del Valle (+ 2006), který nabízí integrální filozofii výchovy, resp. novou paideiu, která je obohacena o personalistický rozměr lásky (Filosofia Integral de la Educación: una Nueva Paideia, 1998; Integral Philosophy of Education: A New Paideia). ${ }^{80}$ Maritainovo přesvědčení o poznávání láskou (per amorem cognoscimus) a nutnosti vychovávat láskou je kategorickým imperativem. Jinak svět nebude obydlen člověkem. Pro člověka není nic velkolepějšího než intuice a láska, které (stejně jako moudrost) nemohou být předmětem výuky. ${ }^{81}$

\section{Závěr}

Z identity současného člověka se stále více vytrácí personálně-bytostní jádro. Maritainova výzva k celostní identitě člověka a k realizaci identity zprostředkované Kristem se stává stále aktuálnější. Jeho pedagogická koncepce garantuje individuální identitu každé osoby a univerzální solidaritu. Jeho dílo zůstává univerzálním nadčasovým poselstvím „caritas humani generis“. Zanechal nám v něm vzkaz, který je apelem na vzkříšení duchovního života a k opravdovému nasazení se

WIESENGANGER, Perspektívy filozofie výchovy..., s. 42.

78 Ján LETZ, Personalistické metafyziky: Křestanská filozofia 20. storočia a jej perspektivy, Trnava: Typi Universitatis Tyrnaviensis, 2006, s. 102.

79 IBARRA, Maritain, Religion and Education..., s. 143.

80 Sabína GÁlIKOVÁ TOLNAIOVÁ, Problém výchovy na prahu 21. storočia, Bratislava: Iris, 2007, s. 146.

81 CIPRO, Prameny výchovy. IV, 20. století..., s. 172. 
pro ideál nového křest’anství a nového člověka. Znovuzrození výchovy a vzdělávání „sub speciae aeternitatis“ - v duchu integrálního humanismu.

\section{Kontakt}

doc. PhDr. Helena Zbudilová, Ph.D.

Jihočeská univerzita v Českých Budějovicích, Teologická fakulta, Katedra pedagogiky

Kněžská 8, 37001 České Budějovice

hzbudilova@tf.jcu.cz 